SCHATTNER, T. G.

\section{Munigua. Un recorrido por la arqueología del municipiem plavium muniguense}

\section{Sevilla: Universidad de Sevilla, 2019}

Esta obra ha sido editada este mismo año por la Universidad de Sevilla y la Junta de Andalucía como número uno de una colección destinada a guías. Respondiendo a la tipología en la que se enmarca la obra pues nos ofrece una guía actualizada de la ciudad arqueológica de Munigua desde el origen de sus investigaciones arqueológicas hasta la actualidad. Coordinada por Thomas G. Schattner (director de las investigaciones desde 1996), la publicación es el resultado de una larga y concienzuda labor de investigación llevaba a cabo por el equipo hispano-alemán encargado del proyecto.

Munigua es un yacimiento arqueológico situado a unos $10 \mathrm{~km}$ del actual municipio de Villanueva del Río y Minas (Sevilla) que reúne restos de varias épocas, desde la prerromana, siglo IV a. de C., hasta el siglo VIII d. de C., habiéndose documentado restos datados de la época de ocupación islámica de la Península Ibérica. El descubrimiento del yacimiento se sitúa en el año 1765 , momento en que ya adquiere una notable importancia como ciudad de época romana debido a que presenta diversas particularidades que la diferencian de forma notable del resto de ciudades de este tipo, no sólo de Italia, sino también de la Península Ibérica, como sus pequeñas dimensiones, la ausencia de urbanismo ortogonal o su Santuario de Terrazas que corona la ciudad.

Precisamente estas páginas nos ofrecen un minucioso y atrayente recorrido por esta extraordinaria ciudad en un texto organizado en distintos capítulos que recogen los aspectos más interesantes de Munigua: historia de Munigua; historia del descubrimiento de Munigua; el territorio, edificios y construcciones; hallazgos movibles; epigrafía; medidas de conservación y restauración y reconstrucción. Como indica el coordinador de la edición en el prólogo, el orden de los capítulos viene determinado por el sentido en que se realiza la visita, lo que podemos traducir como de una presentación a nivel general de la ciudad mediante la que nos introducen en la historia y el territorio de la misma para, más adelante, llevar a cabo un análisis de los edificios que la componen y los hallazgos que se han producido en ella. Tras estos, se incluye un brevísimo capítulo destinado a las medidas de conservación y restauración.

A todo lo anterior se suma un capítulo que incluye diferentes fotografías de las reconstrucciones realizadas de la ciudad, y tres anexos muy útiles que incorporan una cronología de los emperadores romanos, un glosario de términos, un listado de monografías sobre Munigua y un índice de figuras. Todos ellos completan la intención didáctica de la guía y facilitan la comprensión del texto teórico presentado. 
De esta manera, la publicación cumple perfectamente su función como guía de la ciudad pues ofrece información muy detallada que permite adquirir, por una parte las nociones necesarias para recorrer la ciudad arqueológica y, por otra, las herramientas imprescindibles para poder interpretarla y comprender sus particularidades. En este sentido, resultan especialmente interesantes y didácticas las imágenes de las reconstrucciones 3D de Helio Ruizpérez ofrecidas en la guía. Sin embargo se echa en falta un capítulo que recogiera, a modo de conclusión, una reflexión general sobre el estado actual de la investigación en la ciudad y sus retos futuros. Es inevitable destacar que se trata de una obra de divulgación que llega en el momento oportuno teniendo en cuenta desde 2018, a través de los medios de comunicación, se ha dado a conocer la intención de la Junta de Andalucía de mejorar las comunicaciones con el yacimiento con el fin de facilitar su visita y difusión.

Jesica Serrano Granados | historiadora del arte

URL de la contribución <www.iaph.es/revistaph/index.php/revistaph/article/view/4558> 